\title{
Classification of Patients According to the Degree of Dependence on Nursing Care and Illness Severity in a Post-Anesthesia Care Unit
}

\author{
Luciana Bjorklund de Lima ${ }^{1}$ \\ Deise Borges ${ }^{2}$ \\ Samara da Costa ${ }^{2}$ \\ Eneida Rejane Rabelo ${ }^{3}$
}

\begin{abstract}
This study aimed to classify patients according to their degree of dependence on nursing care (Perroca Classification System) and correlate this with the anesthetic risk (American Society of Anesthesiologists - ASA classification) in a post-anesthesia care unit. A crosssectional study was conducted, which included 402 patients, mean age $51.57( \pm 16.73)$ years, of which 216 (54\%) were female. The results indicate that patients had a degree of dependence between intermediate and semi-intensive with an ASA classification of between two and three. There was a significant relationship between degree of dependence and ASA classification. The results indicate that the post-anesthesia care unit admits patients with semi-intensive care requirements and with moderate anesthetic risk.
\end{abstract}

Descriptors: Needs Assessment; Anesthesia Recovery Period; Postanesthesia Nursing.

\footnotetext{
${ }^{1}$ RN, Hospital de Clínicas de Porto Alegre, Brazil. Master's Student, Escola de Enfermagem, Universidade Federal do Rio Grande do Sul, Brazil. E-mail: lubjork@gmail.com.

2 Nursing undergraduate student, Escola de Enfermagem, Universidade Federal do Rio Grande do Sul, Brazil. Email: dborges.enf27@yahoo.com.br, e-mail: samarinha_poa@hotmail.com.

${ }^{3}$ RN, Ph.D. in Biological Sciences, Adjunct Professor, Escola de Enfermagem, Universidade Federal do Rio Grande do Sul, RS, Brazil. Professor, Instituto de Cardiologia, Fundação Universitária de Cardiologia, RS, Brazil. E-mail: rabelo@portoweb.com.br.
}

Corresponding Author:

Eneida Rejane Rabelo

Universidade Federal do Rio Grande do Sul. Escola de Enfermagem.

Departamento de Enfermagem Médico-Cirurgica.

Rua São Manoel, 963

Bairro Rio Branco

CEP: 90620-910 Porto Alegre. RS, Brasil

E-mail: rabelo@portoweb.com.br 


\title{
Classificação de pacientes segundo o grau de dependência dos cuidados de enfermagem e a gravidade em unidade de recuperação pós-anestésica
}

O estudo teve por objetivo classificar os pacientes, segundo o grau de dependência dos cuidados de enfermagem (Sistema de Classificação de Perroca), relacionando-o ao risco anestésico (Classificação da American Society of Anesthesiologists - ASA) em uma unidade de recuperação pós-anestésica. Realizou-se estudo transversal, com inclusão de 402 pacientes com idade média de $51,57( \pm 16,73)$, sendo 216 (54\%) do sexo feminino. Os resultados apontam que os pacientes têm grau de dependência entre intermediário e semi-intensivo com Classificação ASA entre dois e três. Houve relação significativa entre grau de dependência e Classificação ASA. Os resultados indicam que a unidade de recuperação pós-anestésica admite pacientes com cuidados semi-intensivos com moderado risco anestésico.

Descritores: Determinação de Necessidades de Cuidados de Saúde; Período de Recuperação da Anestesia; Enfermagem em Pós-Anestésico.

\section{Clasificación de pacientes según el grado de dependencia de los cuidados de enfermería y de la gravedad en una unidad de recuperación postanestésica}

\begin{abstract}
El estudio tuvo por objetivo clasificar los pacientes según el grado de dependencia de los cuidados de enfermería (Sistema de Clasificación de Perroca) y relacionarlo con el riesgo anestésico (Clasificación de la American Society of Anesthesiologists - ASA) en una unidad de recuperación postanestésica. Se realizó un estudio transversal con inclusión de 402 pacientes, con edad promedio de 51,57 ( $\pm 16,73)$, siendo $216(54 \%)$ del sexo femenino. Los resultados apuntan que los pacientes tienen un grado de dependencia entre intermedio y semi-intensivo con una Clasificación ASA entre dos y tres. Hubo relación significativa entre el grado de dependencia y la Clasificación ASA. Los resultados indican que la unidad de recuperación postanestésica admite pacientes con cuidados semi-intensivos con moderado riesgo anestésico.
\end{abstract}

Descriptores: Evaluación de Necesidades; Periodo de Recuperación de la Anestesia; Enfermería Postanestésica.

\section{Introduction}

Studies related to the dimensioning of nursing staff through the development of patient classification systems (PCS) and mathematical models have emerged from the need for improvements in human resource planning in health institutions ${ }^{(1-3)}$.

The system of classifying patients translates into a key element in the administrative practice. This system permits identification of the patient care profile, to support the re-allocation of human and material resources, to redirect the care dynamic and to determine the costs of nursing care ${ }^{(1-2)}$.

In 1996 a system was developed for classifying patients using 13 critical indicators of care: Mental Status and Level of Consciousness, Oxygenation, Vital Signs, Nutrition and Hydration, Motility, Locomotion, Body Care, Eliminations, Therapeutics, Health Education, Behavior, Communication and Mucocutaneous Integrity(3).

Several studies that have applied this classification system are directed to investigate the degree of dependence on nursing care in inpatient units ${ }^{(3-4)}$. However, a recently published study conducted at a hemodynamics unit, through the application of $\mathrm{PCS}^{(5)}$, found that patients treated in this unit had an intermediate degree of dependence, and concluded that further study is necessary to adequate the dimensionality of nursing staff in this area(5). Another study which applied 
the PCS, performed in a clinic of a public university general hospital, which specializes in the treatment of hepatobiliary diseases, obtained similar results to the study in the hemodynamics unit, being that the patients were classified as intermediate care ${ }^{(6)}$.

The post-anesthesia care unit is characterized as being a specialist unit due to the specificities of the patient care in the immediate post-operative period. Since the literature indicates that the post-anesthesia care unit is characterized as caring for patients with high complexity, often being a site with patients requiring intensive nursing care ${ }^{(7)}$. However, there have been no studies conducted in Brazil that assessed the degree of dependence or severity of patients in this unit.

\section{Aims}

The aims of this study were to classify patients according to their degree of dependence on nursing care and to relate this with the evaluation of anesthetic risk in a post-anesthesia care unit.

\section{Patients and Methods}

This was a prospective cross-sectional study carried out in a Post-anesthesia Care Unit of a university public hospital of the city of Porto Alegre - RS, Brazil. The study period was from September to October 2007.

A convenience sample including patients of both sexes, aged over or equal to 18 years, undergoing any type of anesthetic-surgical procedure was created. No patient was excluded during this study.

Data collection took place from Monday to Friday in the afternoon, a period characterized as having a higher number of admissions to this unit. The instrument used was the Perroca PCS. This system uses 13 indicators of critical care: Mental Status and Level of Consciousness, Oxygenation, Vital Signs, Nutrition and Hydration, Motility, Locomotion, Body Care, Eliminations, Therapeutics, Health Education, Behavior, Communication and Mucocutaneous Integrity. Each indicator has a five points scale in order to categorize the growing intensity of the degree of dependence in relation to nursing care. After application of each of the 13 indicators, the sum of the points classifies the patient into a certain category of care: minimum care (13-26 points), intermediate care (27-39 points), semi-intensive care (40-52 points) and intensive care (53-65 points)(3).

To evaluate the anesthetic risk of the patients the Classification of the American Society of Anesthesiologists
(ASA Classification) was used, which is an anesthesia classification performed by the anesthesiologist, based on the evaluation of the clinical examination of the patient and the presence of comorbidities, having a score of one to six with increasing value according to the anesthetic risk evaluated ${ }^{(8)}$.

To characterize the sample, variables were collected such as age, gender, type of anesthesia, presence of an epidural catheter, analgesia with neuraxial morphine, surgical specialty, length of stay and destination of the patient after discharge from the unit.

This study was approved by the Ethics Committee of the institution under number 07-200 and due to the inability to obtain informed consent from patients, a terms of commitment to using data from medical records was used.

\section{Statistical analysis}

Data were analyzed using the program Statistical Package for Social Sciences 14.0. Continuous variables were expressed as mean and standard deviation or median and $25^{\text {th }}$ and $75^{\text {th }}$ percentiles, presenting or not normal distribution. Categorical data were presented with absolute and relative frequencies.

To calculate the sample size for the estimate of prevalence of the categories of post-operation nursing care, percentages of $5 \%$ for minimum care, $35 \%$ for intermediate care, $40 \%$ for semi-intensive care and $20 \%$ for intensive care, with a confidence interval of $95 \%$ and an absolute margin of error of $5 \%$ were considered, with an estimated total of 384 patients $^{(5)}$. A total of 402 patients were included.

\section{Results}

\section{Demographic and clinical characteristics}

The 402 patients included in this study had a mean age of 51.57 ( \pm 16.73$), 216$ (54\%) were female, 234 (58.2\%) with ASA classification two and 95 (23.6\%) with ASA classification three. General anesthesia was the type of anesthetic most commonly performed in 306 (76.1\%) patients, followed by 91 (22.6\%) subarachnoid blocks. For the surgical specialties, the prevalence was highest for general surgery with 99 (24.6\%) procedures, followed by urology, gynecology and orthopedic/ traumatology with similar percentages. The median length of stay in the unit was 4.83 (0.33 to 53.22) hours. Discharge from the inpatient unit occurred with $327(81.3 \%)$ patients (Table 1$)$. 
Table 1 - Demographic and clinical characteristics of patients in the Post-anesthesia Care Unit. Porto Alegre - RS, 2007

\begin{tabular}{|c|c|}
\hline Characteristics & $\begin{array}{c}n(\%) \\
n=402\end{array}$ \\
\hline Age $\left(\right.$ years) ${ }^{*}$ & $51.57 \pm 16.73$ \\
\hline Gender (female) & $216(54)$ \\
\hline \multicolumn{2}{|c|}{ American Society of Anesthesiologists (ASA) Classification ${ }^{\dagger}$} \\
\hline ASA 1 & $64(15.9)$ \\
\hline ASA 2 & $234(58.2)$ \\
\hline ASA 3 & $95(23.6)$ \\
\hline ASA 4 & $9(2.2)$ \\
\hline \multicolumn{2}{|l|}{ Type of Anesthesia } \\
\hline General anesthesia & $306(76.1)$ \\
\hline Local anesthesia & $18(4.5)$ \\
\hline Sedation & $9(2.2)$ \\
\hline Subarachnoid block & $91(22.6)$ \\
\hline Epidural Block & $49(12.2)$ \\
\hline Epidural catheter & $44(10.9)$ \\
\hline Neuraxial morphine & $63(15.7)$ \\
\hline \multicolumn{2}{|l|}{ Surgical speciality } \\
\hline General surgery & $99(24.6)$ \\
\hline Urology & $58(14.4)$ \\
\hline Gynecology/Obstetrics & $52(12.9)$ \\
\hline Orthopedia/Traumatology & $50(12.4)$ \\
\hline Others & $143(35.5)$ \\
\hline Length of stay (hours) $)^{\ddagger}$ & $4.83(3.50-7.19)$ \\
\hline \multicolumn{2}{|c|}{ Destination of patients after discharge from PACU } \\
\hline Unit of Hospitalization & $327(81.3)$ \\
\hline Domicile & $67(16.7)$ \\
\hline Intensive Care Unit & $8(2.0)$ \\
\hline
\end{tabular}

* Mean and standard deviation

+Media and $25^{\text {th }}$ and $75^{\text {th }}$ percentile.

¥ASA - American Society of Anesthesiologists

¥No patients had ASA classifications 5 and 6 .

Figure 1 shows the distribution of patients by degree of dependence according to the classification system, there was a higher prevalence of patients classified as intermediate and semi-intensive care.

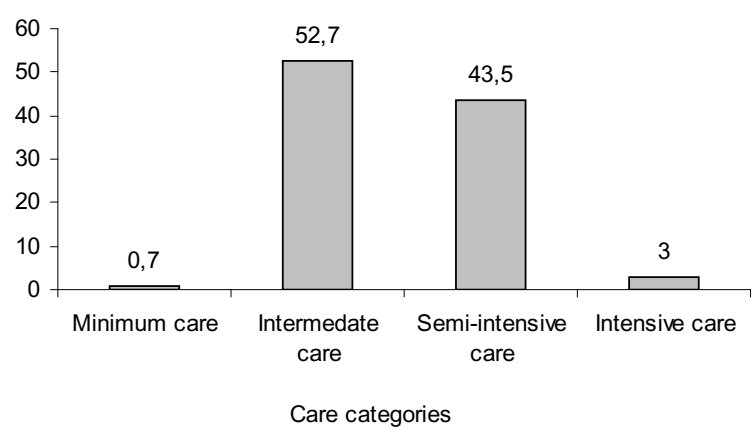

Figure 1 - Classification of patients by degree of dependence on nursing care in the Post-anesthesia Care Unit. Porto Alegre - RS, 2007
The critical indicators of care of the Perroca PCS showed a higher score for vital signs (4.99 \pm 0.18 ) followed by similar values for locomotion, body care, nutrition and hydration, and elimination (Table 2).

Table 2 - Ranking of the critical indicators of care in accordance with the Patient Classification System. PostAnesthesia Care Unit, Porto Alegre - RS, 2007

\begin{tabular}{lc}
\hline \multicolumn{1}{c}{ Critical indicators of care } & Mean $\mathbf{\text { sd }}$ \\
\cline { 2 - 2 } & $\mathbf{n}=\mathbf{4 0 2}$ \\
\hline Vital signs & $4.99 \pm 0.18$ \\
Locomotion & $4.94 \pm 0.41$ \\
Body care & $4.93 \pm 0.42$ \\
Nutrition and hydration & $4.87 \pm 0.56$ \\
Elimination & $4.45 \pm 0.64$ \\
Movement & $3.66 \pm 0.99$ \\
Therapeutics & $2.96 \pm 0.62$ \\
Mucocutaneous integrity & $2.05 \pm 0.3$ \\
Oxygenation & $1.60 \pm 0.82$ \\
Communication & $1.43 \pm 0.96$ \\
Health education & $1.40 \pm 0.88$ \\
Mental state & $1.39 \pm 0.87$ \\
Behavior & $1.15 \pm 0.52$ \\
\hline
\end{tabular}

For the categories of care and length of stay, the median length of stay for patients in the minimal care category was 4.08 ( 3 - 4.91) hours, 4.26 (3.19 to 6.0) hours for patients in intermediate care, 5.50 (4.10 to 12.58) hours for patients in semi-intensive care and 16.91 ( 8.58 to 18.79 ) hours for patients in the intensive care category (Figure 2).

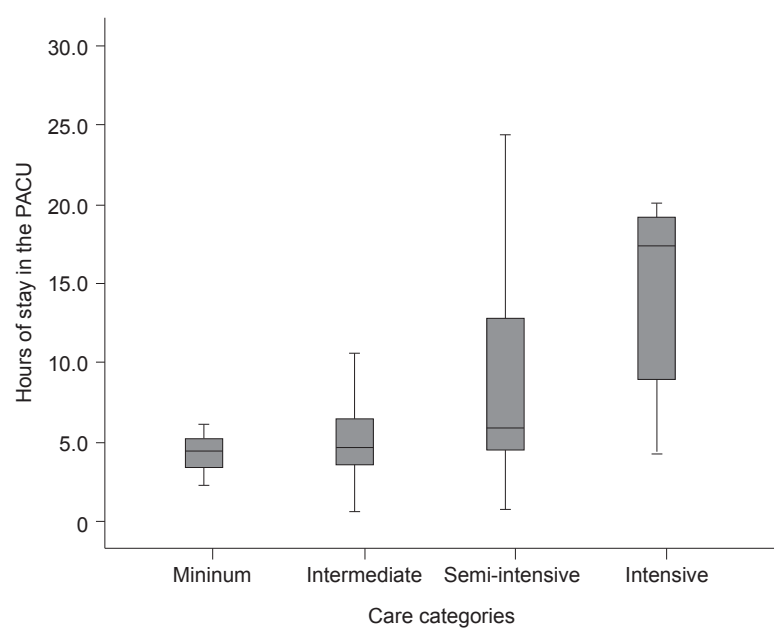

Figure 2 - Hours of stay of patients in the Post-Anesthesia Care Unit by care categories

Porto Alegre - RS, 2007 
According to Figure 3 the median length of stay of patients in the unit according to the ASA classification was 5.68 (4.17 to 17.67 ) hours for patients with ASA classification three, 4.83 (3.58 - 6.55) hours for the patients with ASA classification two, 4.07 (2.62 to 6.06) hours for patients classified with ASA one and 3.08 (2.48 - 4.6) hours for patients classified as ASA four.

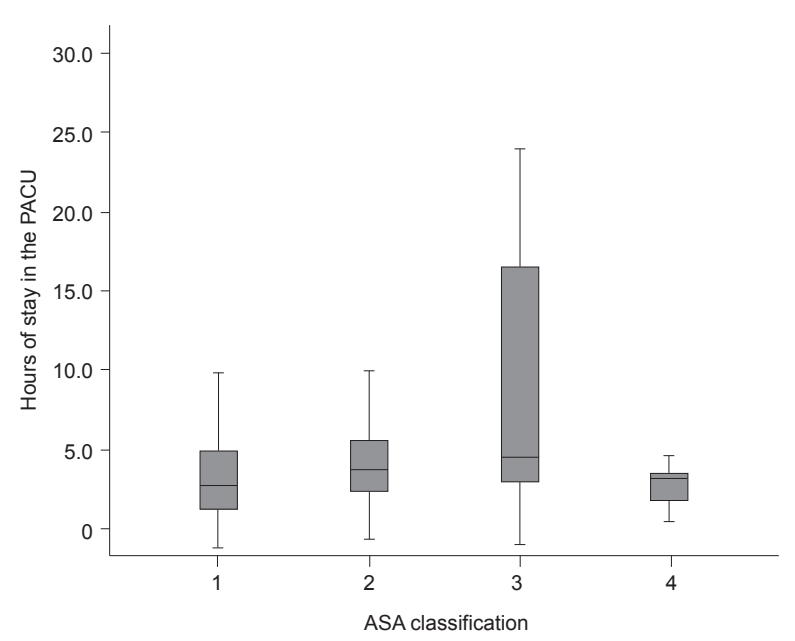

Figure 3- Hours of stay of patients in the PostAnesthesia Care Unit regarding the American Society of Anesthesiologists Classification. Porto Alegre - RS, 2007

\section{Discussion}

This study evaluated the classification of patients regarding their degree of dependence on nursing care related to anesthetic severity in the post-anesthesia care unit.

The data indicated that the classification of the degree of dependence was between intermediate and semi-intensive care, with the vital signs, locomotion, body care, nutrition and hydration, and elimination being the critical indicators of care with higher scores. Results of a study that evaluated the degree of dependence of patients in a hemodynamic unit by applying the PCS identified an intermediate degree of dependence, with predominance in cardiac procedures and local anesthesia. The indicators that contributed most to the increase in the degree of dependence of these patients were vital signs, locomotion, body care and elimination ${ }^{(5)}$. Another study that evaluated the degree of dependence on nursing care in clinical medical and surgical units of a public hospital found that of 18,386 patients classified, around seventy per cent of clinical medical and surgical patients required minimum care. However, a small percentage (less than $2.5 \%$ ) was related to the presence of patients with intensive care requirements. With these data the authors assume that the instrument cannot identify the real profile of complexity of the patients ${ }^{(9)}$.

Despite the difference in the nursing care characteristics in the studies cited, they corroborate our findings, because of the similarity between the high-dependency of the care indicators as well as the presence of patients with intensive care being a reality in different institutions. The patients in a post-anesthesia care unit present specific nursing care requirements with monitoring of vital signs every 15 minutes in the first hour, invasive hemodynamic monitoring, restriction to the bed due to anesthetic awakening, medication administration and procedures for hygiene and comfort. These specificities give the patient in the immediate postoperative period a high degree of dependency on the nursing team, who in addition to these activities, carry out rigorous clinical observation for the management or prevention of hemodynamic instability which requires continuous attention, as well as posses specialized knowledge and skills for taking decisions quickly and precisely.

A significant percentage of the patients had ASA classification two and three, intermediate anesthetic risk. A retrospective study that evaluated the incidence of anesthetic-surgical deaths within the first 24 hours in a university hospital concluded that most deaths occurred among patients with an ASA classification of three or higher(10). A study, evaluating the complexity of nursing care in an intensive care unit for women undergoing gynecological and breast oncology surgery, identified that the degree of postoperative complexity was intermediate, and that the group of hypertensive and elderly women presented high risk for these surgeries $^{(11)}$. It can be inferred that the comorbidities contribute to instability in the immediate postoperative period, because patients with previous diseases such as systemic arterial hypertension, diabetes, cardiopathy and pneumopathy are more susceptible to an increased anesthetic risk, having a higher ASA classification ${ }^{(10)}$. These patients need constant monitoring of vital parameters and close clinical observation to prevent and treat complications arising in the post-operative period.

When the care category was compared with the length of stay, it was observed that patients in the intensive care category have median hours of stay significantly greater than the other categories. A study evaluating factors associated with the workload in the intensive care unit (ICU) demonstrated that the length of stay in 
ICU was a significant factor in elevating the workload of nurses on the first day of the patients' hospitalization(12). An article that questions the use of post-anesthesia care units as intensive care units cites that the mean stay of patients with intensive care requirements in the postanesthesia care unit varies from eight to 72 hours, with a daily average of seven patients in the intensive care category. The author states that the presence of these patients requires better preparation of nurses to meet their care needs and lowers turnover of beds available to meet the operating room demand ${ }^{(7)}$. These studies show that patients with more hours in the unit have a higher degree of dependence on nursing care because of the care and therapy that these patients require. In the post-anesthesia care unit patients in the intensive care category presented needs for invasive hemodynamic monitoring, ventilatory support, measurement of urinary flow, and drainage of catheters and drains among other activities. This scenario entails a permanent decrease in the availability of beds, leading to numerous situations such as delay in the transfer of patients from operating room to the post-anesthesia care unit, delay in the initiation of subsequent surgical procedures and even cancellation of scheduled procedures.

When the hours of stay are analyzed according to the ASA classification, the data show that as this classification increases, the number of hours of stay also increases, with the exception of patients with ASA classification four, which had a lower median of hours of stay. Corroborating the findings, a study that evaluated the relationship of nursing workload with the severity of surgical ICU patients found that as the severity score increases, the number of days in the unit increases, and therefore the need for nursing increases as well(13). Other studies that evaluated the severity and duration of stay of patients admitted to the ICU found that mortality increased parallel to the increase in severity score and that the longer time of stay is associated with the admission of severely ill patients(14-15). Patients with ASA classification four presented a lower median of hours of hospital stay compared to patients with ASA score one, two and three. This may indicate that they were susceptible to greater instability in the immediate postoperative period because of the high anesthetic risk classified. Possibly these patients require intensive care in the immediate postoperative period, having criteria for admission to the intensive care unit (ICU), and therefore presented a lower length of stay due to this indication. For patients with ASA classification three it can be inferred that these remained in the post-anesthesia care unit for longer than others because they did not have criteria for transfer to the inpatient units, but also did not fulfill the criteria for admission to the ICU. These data reveal that the post-anesthesia care unit is an alternative for the treatment of patients with semi-intensive care because of the shortage of intensive care beds and because of the lack of a semi-intensive care unit in the institution.

From these results it appears that the postanesthesia care unit admits patients with moderate anesthesia risk with semi-intensive and intensive care needs. These patients have a greater length of stay compared with patients in other categories of care. Consequently this situation leads to a reduced supply of anesthetic recovery beds as well as the need for adequacy of the workforce for the professional categories of nursing.

\section{Final considerations}

This study, which evaluated the degree of dependence on nursing care associated with the anesthetic risk, showed that the post-anesthesia care unit admits patients with intermediate and semi-intensive care, with a moderate anesthetic risk. It was found that as the hours of stay of a patient in the post-anesthesia care unit increase the greater the degree of dependence on nursing care and the higher the ASA classification.

The admission of patients with indications of intensive care into the post-anesthesia care unit is a current reality, because the increase in the demand of patients prone to hemodynamic instability in the immediate postoperative period is being experienced daily. The post-anesthesia care units become attractive for the admission of these patients due to it being a unit with a physical space and equipment that provides this type of assistance.

The application of the Perroca PCS may be limiting as to the reliable identification of the nursing care profile of patients in the post-anesthesia care unit, which requires association between the clinical characteristics and length of stay to perform a specific analysis for this type of unit.

The identification of the degree of dependence on nursing care, severity of patients, and hours of nursing care are variables that could improve the adequacy of available resources, enabling nurses to communicate with institution administrators, seeking to offer nursing care with safety for the patients and the nursing workers themselves. 


\section{References}

1. Gaidzinski RR. Dimensionamento de pessoal de enfermagem em instituições hospitalares [tese de Livre-Docência]. São Paulo: Escola de Enfermagem/USP; 1998.

2. Vigna $C P$, Perroca MG. Utilização de sistema de classificação de pacientes e métodos de dimensionamento de pessoal de enfermagem. Arq Ciênc Saúde. 2007; 14(1):8-12.

3. Perroca MG. Sistema de Classificação de pacientes: construção e validação de um instrumento. [dissertação]. São Paulo: Escola de Enfermagem/USP; 1996.

4. Fugulin FMT, Gaidzinski RR, Kurcgant P. Sistema de Classificação de Pacientes: identificação do perfil assistencial dos pacientes das unidades de internação do HU-USP. Rev. LatinoAm. Enfermagem. 2005; 13(1):72-8.

5. Hammermüller A, Rabelo ER, Goldmeier S, Azzolin KO. Classificação de pacientes atendidos em uma unidade de hemodinâmica segundo o grau de dependência dos cuidados de enfermagem. Acta Paul Enferm. 2008; 21(1):72-6.

6. Tanos MAA, Massarollo MCKB, Gaidzinski RR. Dimensionamento de pessoal de enfermagem em uma unidade especializada em transplante de fígado: comparação do real com o preconizado. Rev Esc Enferm USP. 2000; 34(4):376-82.

7. Ziser A, Alkobi M, Markovits R, Rozenber B. The postanaesthesia care unit as a temporary admission location due to intensive care and ward overflow. Br J Anaesth. 2002; 88(4):577-9.

8. American Society of Anesthesiologists (ASA). [acesso em: março 2009] Disponível em: http://www.asahq.org/clinical/ physicalstatus.htm.
9. Laus AM. Caracterização dos pacientes internados nas unidades médicas e cirúrgicas do HCFMRP-USP, segundo grau de dependência em relação ao cuidado de enfermagem. Rev. Latino-Am. Enfermagem. 2004; 12(4):643-9.

10. Chan RPC, Auler JOC Júnior. Estudo retrospectivo da incidência de óbitos anestésico-cirúrgicos nas primeiras 24 horas. Revisão de 82.641 anestesias. Rev Bras Anestesiol. 2002; 52(6):719-27.

11. Rosa TSM. Avaliação da complexidade dos cuidados de enfermagem em unidade de terapia intensiva para mulheres submetidas à cirurgia oncológica-ginecológica e mamária. [dissertação]. Campinas: Faculdade de Ciências Médicas/ UNICAMP; 2005.

12. Gonçalves LA, Padilha KG. Fatores associados à carga de trabalho de enfermagem em unidade de terapia intensiva. Rev Esc Enferm USP. 2007; 41(4):645-52.

13. Balsanelli AP, Zanei SSSV, Whitaker IY. Carga de trabalho de enfermagem e sua relação com a gravidade de pacientes cirúrgicos em UTI. Acta Paul Enferm. 2006; 19(1):16-20.

14. Feijó CAR, Leite FO Júnior, Martins ACS, Furtado Júnior AH, Cruz LLS, Menese FA. Gravidade de pacientes admitidos à Unidade de Terapia Intensiva de um Hospital Universitário Brasileiro. Rev Bras Terap Intensiva. 2006; 18(1):18-21.

15. Abelha JF, Castro MA, Landeiro NM, Neves AM, Santos CC. Mortalidade e o tempo de internação em uma Unidade de Terapia Intensiva Cirúrgica. Rev Bras Anestesiol. 2006; 56(1):34-45. 